\section{Pharmacy trust}

Sir, although dentistry is currently developing its own new 'normal' practice, remote prescribing for emergency supply using AAA (advice, analgesia and antibiotics) is still important, especially for vulnerable and shielded patients.

Our pharmacy colleagues have been flexible in their approach to accept and dispense medication from remote prescriptions. The protocol outlines that we should email scanned prescriptions via nhs. net secure accounts. Following this, we are obliged to post the paper prescription within 72 hours recorded delivery.

Pharmacies are dispensing medications upon receipt of scanned prescriptions, but they can only get paid if they obtain the hard copies. The pharmacist's decision to dispense is reliant on trust between the two professions. From personal experience, in recent weeks, there has been more resistance from our pharmacy colleagues to accept dental prescriptions. At some pharmacies this has escalated to a blanket ban. This is due to physical copies not being posted and therefore, the pharmacies not getting paid.

We should ensure hard copies of prescriptions are posted within 72 hours of sending the remote versions and strive to maintain the mutual trust between dentists and pharmacists.

L. Slater, Hull, UK https://doi.org/10.1038/s41415-020-2010-z

\section{Rubber dam evidence}

Sir, we read with interest the correspondence by C. Emery and R. Chate (BDJ 2020; 229: 4-5) advocating the use of rubber dam as an infection control precaution. In response to the COVID-19 pandemic, we undertook a rapid literature review on the effectiveness of rubber dam in reducing the risk of transmission of microbial pathogens during dental aerosol-generating procedures (AGPs).

Six studies ${ }^{1,2,3,4,5,6}$ produced a broad consensus that the use of rubber dam during dental AGPs is effective at reducing the spread of spatter by $33 \%$, as well as reducing surface contamination with bacteria by $80-99 \%$ at a distance of up to one metre. One exception ${ }^{7}$ suggested that rubber dam could deflect spatter onto the dentist's head; however, this is unlikely to be of clinical significance provided the dentist wears appropriate personal protective equipment.

Unfortunately, no studies investigated the effectiveness of rubber dam in preventing transmission of viral pathogens. While it might be reasonable for practical purposes to infer that rubber dam would reduce viral contamination as well, this is clearly a topic that deserves investigation. Using viral transport media for subsequent amplification by polymerase chain reaction, then reporting viral load data, would enable quantification of the impact of rubber dam on viral transmission.

D. Scott, Dundee, T. Hogan, Kent, J. John, Southampton, UK

\section{References}

1. Stevens R E Jr. Preliminary study - air contamination with microorganisms during use of the air turbine handpiece. JADA 1963; 66: 237-239.

2. Miller R L, Burton W E, Spore R W. Aerosols produced by dental instrumentation. Proc First Internat Sym Aerobiol 1963; 97-120.

3. Cochran M A, Miller C H, Sheldrake M A. The efficacy of the rubber dam as a barrier to the spread of microorganisms during dental treatment. JADA 1989; 119: 141-144.

4. Samaranayake L P, Reid J, Evans D. The efficacy of rubber dam isolation in reducing atmospheric bacterial contamination. ASDC J Dent Child 1989; 56: 442-444.

5. Tag El-Din A M, Ghoname N A E-H. Efficacy of rubber dam isolation as an infection control procedure in paediatric dentistry. E Mediterr Health J 1997; 3: 530-539.

6. Dahlke W O, Cottam M R, Herring M C, Leavitt J M, Ditmyer M M, Walker R S. Evaluation of the spatter-reduction effectiveness of two dry-field isolation techniques. JADA 2012; 143: 1199-1204.

7. Al-Amad S H, Awad M A, Edher F M, Shahramian K Omran T A. The effect of rubber dam on atmospheric bacterial aerosols during restorative dentistry. J Infect Public Health 2017; 10: 195-200.

https://doi.org/10.1038/s41415-020-2011-y

\section{Pharmacology}

\section{Metronidazole and alcohol}

Sir, we are writing to draw attention to some interesting research that questions the validity of the disulfiram-like reaction between metronidazole and alcohol. This reaction is the reason the British National Formulary ${ }^{1}$ advises to avoid alcohol during and for 48 hours after taking metronidazole. Giving this advice is standard practice amongst most clinicians.

Disulfiram is a drug used to discourage alcohol consumption. Its interaction with alcohol leads to acetaldehyde accumulation causing symptoms such as skin redness, palpitations, nausea, vomiting, headache and in severe cases circulatory collapse. ${ }^{2}$ The disulfiram-like reaction of metronidazole and alcohol is said to be similar, and was traditionally explained by the same mechanism, although this now seems to be incorrect. ${ }^{2,3,4}$ Its frequency is unclear as figures vary between 0 and $100 \%{ }^{5}$
Its validity has been repeatedly questioned in the modern literature. Serious reactions including at least one death have been attributed to it, ${ }^{3,5}$ although at least some of these have been disputed. ${ }^{3}$ A number of clinical studies and reviews have found evidence of the existence of this interaction to be absent or weak. ${ }^{2,3,4,6}$

Although we do not seek to promote alcohol intake, the advice to abstain completely will restrict patient lifestyle for that period. There are situations such as alcohol dependent patients where this could be especially problematic, so settling this is important.

Overall the evidence for this reaction appears to be weak at best. It appears likely that the concern attached to it is overstated. The purported reaction could actually be an alcohol-independent side effect of metronidazole, an effect of alcohol, or disease - possibilities not adequately eliminated by the studies. ${ }^{2}$ Furthermore, the term 'disulfiram-like' is a misnomer, at least in a biochemical sense, as it seems that any such reaction does not occur through the same mechanism as disulfiram. Conversely, no definite evidence is presented that this reaction does not occur - perhaps it occurs only in a small subgroup. The aim of this letter is not to suggest we, as clinicians, stop advising patients to avoid alcohol whilst on metronidazole. Rather all clinicians should be alert to its weak evidence base and be ready to question and reject long-held beliefs and mantras such as this should new evidence emerge.

B. J. Steel, C. Wharton, Tyne \& Wear, UK

\section{References}

1. British National Formulary. Metronidazole - interactions. 2020. Available at: https://www. medicinescomplete.com/\#/content/bnf/_555910287_interactions (accessed April 2020).

2. Fjeld $\mathrm{H}$, Raknes $\mathrm{G}$. Er det virkelig farlig å kombinere metronidazol og alkohol? Nor Legeforen 2014; 134 1661-1663 [translated into English].

3. Williams C S, Woodcock K R. Do ethanol and metronidazole interact to produce a disulfiram-like reaction? Ann Pharmacother 2000; 34: 255-257.

4. Visapää J-P, Tillonen J S, Kaihovaara P S et al. Lack of di- 